\title{
The Evolution of Inequality: War, State Survival, and Democracy in Comparative Perspective by Manus I. Midlarsky (1999), Stanford, CA: Stanford University Press, xiv, 349 pp. Reviewed by Patricia Kachuk, Lecturer, Department of Anthropology and Sociology, University of British Columbia.
}

\section{Reviewed by Manus Midlarsky, Department of Political Science, Rutgers University, New Brunswick, NJ.}

Rarely does one see a review that misses the mark in so many areas. Patricia Kachuk's review of my book The Evolution of Inequality: War, State Survival, and Democracy in Comparative Perspective appearing in Volume 6 of the Journal of Political Ecology, happens to be one such rarity. At first, I wasn't even sure the reviewer read the book that I wrote, until I realized that in her review, my book had been distorted virtually beyond recognition. Errors are found in at least four areas. They include misunderstanding, if not outright misrepresentation of 1) intent of the book, 2) specifics of the theory, 3) conclusions from case studies, and 4) the nature of social science modeling.

Intent of the book:

My purpose in examining democracy clearly was to comprehend the sources and workings of democracy, if only to better understand the democratic peace, a dominant theory in international politics (my primary field of study), which holds that democracies do not make war on each other. Somehow Ms. Kachuk understood this as, "Midlarsky's focus is on how democracies are necessary to keep internal peace by justifying the extreme inequalities within the state in such a way that those who suffer most will continue to believe that supporting those who rule will be in their own best interests, thus protecting the state from any external threat of political violence." After making some sense of this passage, I reluctantly came to the view that only a totalitarian sensibility could have yielded this conclusion, which is quite the opposite of my statements in the book. There, democracy as a sham and opiate of the masses implied by the reviewer is explicitly criticized by me in the context of my denial of the validity of Marxist-Leninist "derogation of parliamentary democracy as a sham foisted on a virtually helpless public by the landed elite. For parliaments changed, and gradually the earlier control by the elite gave way to more inclusive forms" (p.14).

Specifics of the theory:

In a similar vein, my use of the word "genetic" once at the beginning of the book and twice in one paragraph towards the end of the concluding chapter suggesting some possible implications of the theory, was transformed into a basic component of the theory mentioned five times in her review. Perhaps this is one measure of the extent of Ms. Kachuk's distortions; a word used three times in a 349 page book is mentioned now five times in a 2-3 page review. The book index has not a single entry for either the word "gene" or "genetic." Although my initial mention of genetics was drawn from a quote emanating from Darwinian theory, upon reflection I now believe that there are more important reasons for differential rates of expansion among human groups. Several of these include the overwhelming size of one ethnie relative to another that enables the former to expand its territorial holdings, disparities in levels of militarization between groups, geopolitical vulnerabilities of certain ethnies relative to others, or simply the luck of the draw in having empty space adjacent to a potentially expanding population. But the reason for expansion is not a basic argument of the book. Instead, it is the expansion itself in a fractal pattern establishing the foundation for state formation that is fundamental. This basic fact appears to have eluded Ms. Kachuk.

It certainly was not genetics that led the British, Jamaicans, Icelanders, or Trinidadians to be more democratic than others, but island locations that maximized state security and allowed democracy to flourish, as I point out in the book. My use of the word "genetic" in the conclusion, explicitly constrained I might add by the artifice of differential birth rates between the intellectually gifted and those less fortunate, was limited to the question of the potential scarcity of human resources in a technological age to be coupled with the ongoing debate over the scarcity of non-human resources. My solution to the possible existence of such a problem was to suggest a vigorous education program, hardly an emphasis on genetics. For the sake of symmetry and completeness I included availability of human resources in addition to non-human; somehow this brief mention of genetics became the basis for the entire theory in the reviewer's mind.

The basics of the theory are not understood by Ms. Kachuk, else she could not ask "why the ultimate winners in this random process, by his own analysis, are always white males of Western European descent." The answer given by my analysis is simple ${ }^{\circledR} \varnothing$ they were the first to expand globally in a fractal formation by virtue of 
Reviews

competition among their states and a consequent resort to new technologies and navigation methods, among other reasons. I even included in Chapter 2 a test of the fractal model applied to colonial populations governed by European powers in 1914. And the "ultimate winners," of course, are not "always white males of Western European descent," as the vast decolonization process of the 20th century amply demonstrated.

Conclusions from case studies:

Here, I am quoted and criticized for taking seriously the Roman example and Arnold Toynbee's finding of a threat to societies from internal immigrant populations collaborating with their external counterparts. As one might expect, the context consisting of at least three counterarguments is not mentioned. In the paragraph immediately following this quote, I state, "Again, however, the presence of democratic procedures, the possibility of electing representatives from the new immigrant groups, and other mechanisms of redress distinguish these more contemporary instances from that of Rome" (p. 273). Geopolitical configurations enhancing the security of North America, Western Europe, and Japan also render this aspect of the Roman example and the Toynbee model less applicable to Western democracies, as I indicate in the succeeding paragraph. On the following page, I suggest that probably a greater danger to Western democracies arises from the process of elite withdrawal into an international culture of work and leisure, identified by Christopher Lasch. I wrote, "This orientation away from the state · is eerily reminiscent of the later Roman Empire. The commonalities of ethnicity and language between the 'internal' and 'external' Germanic elements, combined with political collusion by large landowners, are here replaced by commonalities of workplace, work 'language,' and ultimately shared values of this internationalized privileged class" (p.274). This process is intimately related to the issue of state survival under globalization conditions examined in a recent Foreign Affairs article by Martin Wolf.

On the matter of a probable threat of warfare from the Islamic world argued by Samuel Huntington, I explicitly stated: "Results of this study suggest that such conflict is not likely in the foreseeable future, if only because there are certain compatibilities between democracy and Islam that deny the mutual-exclusivity hypothesis" (p. 227). As a consequence of the democratic peace, the Islamic world should not be a threat. Once again, the book speaks for itself when confronted with these misguided, if not misrepresented challenges.

Nature of social science modeling:

At the end of her review, Ms. Kachuk's rejection of simplification in modeling brings to mind Henri Theil's injunction that models are not to be believed, but are to be used. That is, a model is not to be judged by how much it simplifies, but by the outcomes of research stemming from its usage. In my book, understanding the rise and fall of states including the sources of democracy, the finding of patterned inequality in the onset of Latin American political violence and the urban disorders of the $1960 \mathrm{~s}$, the awful consequences of African-American ghettoization during that period, the necessity for redistribution, the virtues of social mobility for state survival, altruism under conditions of equality during the Holocaust, and circumstances fostering gender equality, I think amply justify the simplifying assumptions required for the construction of my model. And these emphases constitute virtually the entire book. It is a pity that Ms. Kachuk, whatever her personal agenda, could not concentrate on this large body of material readily available for her review.

\section{Smokestack Diplomacy: Cooperation and Conflict in East-West Environmental Politics, by Robert G. Darst. Cambridge, MA: The MIT Press (2001), xii, 300 pp.}

\section{Reviewed by Barbara A. Cellarius , Max Planck Institute for Social Anthropology, Halle/ Saale, Germany.}

With the fall of the Berlin Wall, disintegration of the Soviet Union, and subsequent end of the Cold War, environmental issues in former socialist bloc countries have received considerable attention from scholars in many disciplines. The reasons for this are many, including increased access both to archives and ordinary people (at least in some countries), interest in the aftermath of the Cold War and the 'transition' from socialism, and increased contact with and influence of the West in such countries. A recent contribution to this literature is Smokestack Diplomacy, the latest book in the MIT Press's series on Global Environmental Accord: Strategies for Sustainability and Institutional Innovation. In it, Robert Darst, a political scientist, analyzes transnational efforts to promote 